
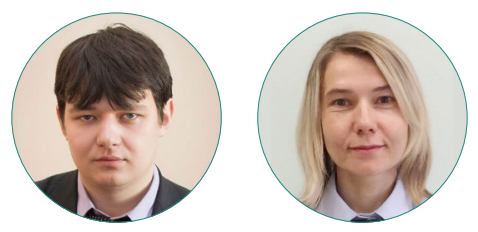

С. Г. Ушкин, Е. А. Коваль

\title{
ОБОСНОВАНИЯ ПРИНЯТИЯ РЕШЕНИЙ БУДУЩИМИ РОССИЙСКИМИ ЮРИСТАМИ В УСЛОВИЯХ ЦЕННОСТНО-НОРМАТИВНОЙ НЕОПРЕДЕЛЕННОСТИ: AEQUITTAS SEQUITTUR LEGEM?
}

\section{Правильная ссылка на статью:}

Ушкин С. Г., Коваль Е. А. Обоснования принятия решений будущими российскими юристами в условиях ценностно-нормативной неопределенности: aequitas sequitur legem? // Moниторинг общественного мнения: экономические и социальные перемены. 2021. № 3. C. 472-491. https://doi.org/10.14515/monitoring.2021.3.1885.

\section{For citation:}

Ushkin S. G., Koval E. A. (2021) Justification of Decision-Making by Future Russian Lawyers in the Conditions of Value and Normative Uncertainty: Aequitas Sequitur Legem?. Monitoring of Public Opinion: Economic and Social Changes. No. 3. P. 472-491. https://doi.org/10.14515/ monitoring.2021.3.1885. (In Russ.) 
ОБОСНОВАНИЯ ПРИНЯТИЯ РЕШЕНИЙ БУДУЩИМИ РОССИЙСКИМИ ЮРИСТАМИ В УСЛОВИЯХ ЦЕННОСТНО-НОРМАТИВНОЙ НЕОПРЕДЕЛЕННОСТИ: AEQUĪTAS SEQUITTUR LEGEM?

Ушкин Сергей Геннадьевич - кандидат социологических наук, ведущий научный сотрудник отдела мониторинга социальных процессов, Научный центр социально-экономического мониторинга, Саранск, Россия

E-MAIL: ushkinsergey@gmail.com

https://orcid.org/0000-0003-4317-6615

КОВАЛЬ Екатерина Александровна доктор философских наук, главный научный сотрудник отдела научных исследований, Средне-Волжский институт (филиал) Всероссийского государственного университета юстиции (РПА Минюста России), Саранск, Россия E-MAIL: nwifesc@yandex.ru https://orcid.org/0000-0003-0069-5335

Аннотация. Профессиональная карьера зависит от ряда факторов объективного и субъективного характера. К последним, в частности, относятся ценностно-нормативные ориентации личности, характеризующие мировоззрение, уровень правовой культуры, моральное сознание. Они не только указывают на личностные особенности профессионалов, но и обладают прогностическим потенциалом для выявления установок на обоснование решений в условиях ценностнонормативной неопределенности.

Особую ценность представляет исследование обоснования принятия решений теми, кто имеет возможность оперировать нормами, регулирующими отдельные социальные практики
JUSTIFICATION OF DECISION-MAKING BY FUTURE RUSSIAN LAWYERS IN THE CONDITIONS OF VALUE AND NORMATIVE UNCERTAINTY: AEQUITTAS SEQUITTUR LEGEM?

Sergey G. USHKIN ${ }^{1}$ - Cand. Sci. (Soc.), Leading Researcher at the Social Processes Monitoring Department

E-MAIL: ushkinsergey@gmail.com

https://orcid.org/0000-0003-4317-6615

Ekaterina A. KOVAL ${ }^{2}-$ Dr. Sci. (Phil.), Chief Research Fellow at the Department for Scientific Research

E-MAIL: nwifesc@yandex.ru https://orcid.org/0000-0003-0069-5335

\footnotetext{
${ }^{1}$ Scientific Centre for Social and Economic Monitoring, Saransk, Russia

2 All-Russian State University of Justice (Mid-Volga Branch), Saransk, Russia
}

Abstract. A professional career depends on a number of objective and subjective factors. The latter, in particular, include individual values and normative orientations, which characterize the worldview, the level of legal culture, and moral consciousness. They not only indicate the personality traits of professionals, but also have predictive potential for identifying attitudes towards justifying decisions in conditions of value and normative uncertainty.

The study of the rationale for decision-making by those who have the opportunity to operate with the norms, regulating individual social practices and social relations in general, is particularly important. Such opportunities are possessed by representatives of le- 
и общественные отношения в целом. Такими возможностями обладают представители юридических профессий, специализирующиеся в области нормотворчества и нормоприменения, то есть во многом определяющие ценностно-нормативную структуру общественного устройства. Изучение способов обоснования принятия решений в условиях ценностно-нормативной неопределенности профессионалами или будущими профессионалами позволяет в некоторой степени конкретизировать содержание представлений о социальной справедливости и действующих социальных нормах, а также оценку последних респондентами с точки зрения соотношения закона и справедливости.

С этой целью было проведено авторское социологическое исследование обучающихся на базе филиалов Всероссийского государственного университета юстиции (РПА Минюста России), расположенных в восьми российских городах - Ижевске, Казани, Калуге, Петрозаводске, Саранске, Санкт-Петербурге, Туле и Хабаровске. Всего опрошено 415 человек, по 10\% от общей численности студентов очной формы обучения в каждом филиале, квотированных по полу и возрасту. Там, где было возможно, результаты сопоставлены с результатами исследования, проведенного по сходной методике в 2016 г. $(N=374)$.

Результаты исследования показали значимость проблемы соотношения закона и справедливости в представлениях студентов юридических специальностей и направлений подготовки. Выделено четыре модели: утилитаристская, либеральная, социалистическая gal professions specializing in the field of rulemaking and enforcement, that is, in many respects determining the value-normative structure of the social order. The study of the ways professionals or future professionals justify decision-making in conditions of value-normative uncertainty allows, to some extent, to concretize the content of ideas about social justice and existing social norms, as well as individual evaluation of the latter from the point of view of the relationship between law and justice.

For this purpose, the authors carried out a sociological study on the basis of branches of the All-Russian State University of Justice (RLA of the Ministry of Justice of Russia) located in eight Russian cities - Izhevsk, Kazan, Kaluga, Petrozavodsk, Saransk, St. Petersburg, Tula, and Khabarovsk. The sample consisted of 415 respondents and covered $10 \%$ of the total number of full-time students in each branch; the selection process involved quotas by gender and age. Where possible, the results were compared with the results of a similar study conducted in $2016(N=374)$.

The study proved the perception of the correlation between law and justice by students of legal specialties to be an important issue. The authors distinguished four models of attitudes: utilitarian, liberal, socialist, and fatalist. The choice of the model largely determines the attitude towards social practices, which are problematized in the public consciousness and are perceived as either non-normative or ambiguous. 
и фаталистская. Выбор модели во многом определяет отношение к социальным практикам, которые проблематизируются в общественном сознании и воспринимаются или как ненормативные, или как неоднозначные.

Ключевые слова: закон, справедливость, нормативно-ценностные установки, нормотворчество, ценностнонормативная неопределенность

Благодарность. Статья подготовлена при финансовой поддержке РФФИ (проект № 19-011-00082).
Keywords: law, justice, normative orientations, values, value and normative uncertainty, rulemaking

Acknowledgments. The research was supported by RFBR, project № 19-01100082.

\section{Введение}

Ценностно-нормативные ориентации и установки, приобретаемые человеком по мере взросления, накладывают отпечаток на его профессиональные траектории. Особенно это касается профессий, требующих постоянного взаимодействия с другими людьми, применения к ним и себе процедуры моральной оценки - начиная от школьных учителей и заканчивая священнослужителями. Отмечается, что «оценка человеком самого себя как морального субъекта представляется важным предиктором социального поведения индивида, его установок и качества жизни, а также позволяет пролить свет на механизмы конструирования, поддержания и защиты моральной Я-схемы как особого вида социальной идентичности" [Настина, Девятко, 2021: 18].

Особое место в этом континууме занимают юристы, деятельность которых сосредоточена на защите гражданских прав и свобод, нормативном регулировании повседневной жизни. Одни авторы полагают, что ядром их мировоззрения должна быть социальная справедливость, поскольку именно юристы призваны защищать обездоленных и изолированных членов общества [Sangroula, 2020]; другие, напротив, отдают предпочтение верховенству закона в юридическом образовании [Tan, 2011].

Ориентация преимущественно на собственную выгоду, закон или социальную справедливость предопределяет карьерные ориентации будущих юристов [WaiSang Wu, Wing-Hung Lo, Liu, 2020]. Поскольку юристы делают существенный вклад в нормативно-правовое регулирование общественных отношений, от того, какие представления о законе и справедливости были усвоены ими, во многом зависит конструирование и воспроизводство ценностно-нормативных кодов, характерных для всего общества. Как отмечают западные исследователи, само по себе знание закона далеко не всегда является определяющим, если при этом игнорируются общественные идеалы [van Schilfgaarde, 2019]. Более того, отдельные представители юридического корпуса способны быть воплощением нравственности, или, 
напротив, безнравственности, и на их примере можно оценивать уровень государственного и общественного развития (это показательно при ведении громких судебных процессов: "Дело Мамаева и Кокорина", "Дело Ефремова", "Дело Навального" и др.).

Природа юридической аргументации такова, что, несмотря на жесткую нормативную регламентацию процедур принятия решений, требуется и носитель морального сознания, способный учитывать содержание ценностно-нормативных кодов общества. По этой причине невозможно алгоритмизировать принятие юридически значимых решений в ситуациях нормативной неопределенности. Как отмечает Р. Биннс, «понятие индивидуальной справедливости может быть осмысленно реализовано только через человеческое суждение" [Binns, 2020].

Под ценностно-нормативной неопределенностью мы понимаем ситуации, в которых решение приходится принимать в отсутствие четких нормативных механизмов (“серые зоны”, моральные дилеммы и т. п.), опираясь в основном на личное усмотрение. Подобного рода ситуации постоянно возникают в рамках правоприменительной деятельности, которой занимаются юристы. Так, судьи, принимающие решение по семейным спорам, руководствуются не только законом, но и совестью, и последней - в большей степени, поскольку закон, например, не содержит ответа на вопрос, с кем из разводящихся родителей оставить ребенка, если оба родителя имеют условия для его содержания, законопослушны и желают, чтобы ребенок проживал с ними.

Наша цель - детально рассмотреть нормативно-ценностные ориентации и установки студентов юридических специальностей и направлений подготовки (не все из них обязательно станут нормотворцами и нормоприменителями, однако определенные тренды, характерные для отрасли в целом, могут быть выделены). Особый интерес для нас представляет изучение взаимосвязи в сознании будущих юристов между законностью и справедливостью, поскольку степень ее наличия или отсутствия, на наш взгляд, определяет моральные ориентиры общества в целом, не ограничиваясь узкой профессиональной группой.

\section{Теоретическая основа и проблема исследования}

Взаимосвязь законности и справедливости, их общие и специфичные моменты изучены недостаточно [Катомина, Санисалова, 2013: 40], а оптимальный баланс между ними отсутствует [Цыбулевская, Милушева, 2017: 59]. Исследователи подчеркивают, что "право в жизни общества, будучи государственно санкционированным, должно так или иначе поддерживать правовыми нормами простые, элементарные требования справедливости" [Черняева, 2009: 126]. Например, Н. Е. Тихонова, в период с 1995 по 2010 г. исследовавшая динамику ценностнонормативных установок россиян, в том числе соотношения закона и справедливости, отмечает, что “...хотя группа считающих, что не так важно, соответствует что-либо закону или нет - главное, чтобы это было справедливо, по-прежнему очень многочисленная, все же впервые за время наблюдений она стала составлять в 2010 г. менее $50 \%$, сократившись за 15 лет примерно на четверть в относительном выражении..." [Тихонова, 2011: 62]. Данная тенденция осталась актуальной и во втором десятилетии XXI века, хотя приоритет закона перед 
справедливостью обнаружился далеко не для всех групп граждан. Так, парадоксальным образом, образованные молодые люди чаще иных групп респондентов делают выбор в пользу социальной справедливости, а не законопослушности [Козырева, Смирнов, 2020: 84].

Проблема заключается в том, что, начиная от Платона и заканчивая Дж. Ролзом, интерпретации понятия справедливости являются в высокой степени спекулятивными. Что такое справедливость? Насколько она достижима? Справедливость для кого должна быть установлена? Это только ряд вопросов, которые приобретают все большую остроту в российском обществе, поскольку, по данным фокус-групповых исследований, ни эксперты, ни чиновники, которые их нанимают, не обсуждают признаки справедливости или несправедливости в различных жизненных ситуациях [Римский, 2019: 172]. Возможный ответ на них предлагает А. Сен, который считает обоснованным отказ от утопических проектов справедливого общества со справедливыми институтами, где трансцендентальный институционализм должен быть заменен сравнительным методом [Сен, 2016].

Требования законности также неоднозначны, что особенно проявляется в ситуациях ценностно-нормативной неопределенности. Эта интуиция нашла свое отражение в так называемых правилах Макнотена, которые представляли собой ряд четких критериев для признания подсудимого ответственным за свои действия, даже если он страдает от помутнения рассудка; довольно быстро из предмета юридического спора они стали источником новых литературных, философских, психологических и социологических прозрений [Вахштайн, 2015: 8].

Поскольку практика правоприменения весьма разнообразна, на институциональные предпосылки соблюдения принципов законности и справедливости накладываются моральные аберрации, которые приобретаются на основе собственного чувственного опыта индивидов и институциональных особенностей их становления и развития. Рассмотрению различий несовпадающих трактовок справедливости в юридической практике посвящен мысленный эксперимент Л.Л. Фуллера, получивший название "дело спелеологов" [Фуллер, 2017]. Он наглядно иллюстрирует водораздел между различными теориями права, влияющими на принятие решений, среди которых главные - естественное право и правовой позитивизм.

В центре эксперимента - судьба пятерых мужчин, отправившихся на исследование глубокой пещеры. Вскоре после того, как они в ней оказались, случился камнепад, полностью заблокировавший единственный выход. Работы по их спасению были долгими, во время операции погибло десять рабочих. Только на двадцатый день удалось установить радиосвязь с запертыми в ловушке спелеологами. Спасатели объявили, что им потребуется еще десять дней для того, чтобы их вытащить. Оценив количество оставшейся еды при помощи врача, мужчины поняли, что не смогут продержаться. Тогда они спросили, будет ли у них шанс выжить, если они съедят одного из своих товарищей. Им неохотно ответили, что такой шанс будет, но никто - ни врач, ни священник, ни философ-не дал какого-либо совета.

На тридцать второй день спелеологов нашли спасатели. Но, как выяснилось, четверо из них, чтобы выжить, съели пятого. Именно он предложил идею съесть одного, чтобы спаслись остальные. Ему же принадлежала идея со жребием. Однако, 
когда пришло время бросать жребий, он отказался это делать, разочаровавшись в своих идеях. К сожалению, жребий бросили за него, и судьба быть съеденным компаньонами выпала этому спелеологу.

Было проведено расследование, и присяжные вынесли решение о виновности спелеологов в умышленном убийстве и применении к ним смертной казни через повешение, а суд по общим делам закрепил это решение. Тем не менее была подана апелляция. Главный судья Верховного суда согласился с доводами присяжных, но сослался на неоднозначные обстоятельства дела и предложил коллегам подтвердить вынесенный приговор и попросить помилования у главы исполнительной власти. После были заслушаны позиции оставшихся четырех судей.

Первый судья высказался в пользу оправдания спелеологов. По его мнению, спелеологи, запертые волею случая в пещере наедине друг с другом, оказались вне действующего правового поля, как если бы перенеслись на необитаемый остров или на чужую территорию. Поэтому единственные правовые нормы, которые могли быть применимы в этой ситуации, определялись на основании договора между ними. Также он указал на то, что во имя спасения спелеологов погибли десять рабочих. Наконец, важное замечание касалось различия буквы закона и цели его исполнения. В частности, он привел довод, что нельзя осуждать голодающих людей, которые фактически действовали в целях необходимой самообороны.

В его рассуждении приоритет перед позитивным правом имеет право естественное, причем преимущества последнего столь велики, что в описываемом случае судья полагает возможным не только отказаться от применения закона, но и признать следование ему неразумным. В данной модели рассуждений справедливость имеет очевидное преимущество перед писаным законом.

Второй судья категорически не согласился с высказанными аргументами и отстранился от рассмотрения дела. Он посчитал неприемлемым применить вместо писаного закона нормы так называемого естественного кодекса, согласно которому человек может заключить договор, позволяющий компаньонам съесть его тело и не иметь возможности этот договор расторгнуть. Не меньшее отторжение вызвала у второго судьи и идея интерпретировать закон так, как удобно в конкретном случае. Однако применение закона настолько противоречило его чувству справедливости, что он отказался принимать решение.

Третий судья принял доводы главного судьи лишь частично, а аргументы первого признал несостоятельными. По его мнению, факты однозначно указывали на совершенное преступление, а все остальное несущественно. Прошение о помиловании в этой ситуации он счел недопустимым ввиду того, что судьям не должно переписывать законы или вмешиваться в работу других ветвей власти.

Четвертый судья пришел к выводу, что обвиняемые невиновны, но не потому, что это соответствует принципам законности, а потому, что фактами управляют другие люди. Так, он приводит результаты опроса общественного мнения, где абсолютное большинство опрошенных выступало за полное помилование или символическое наказание. Его логика исходит из того, что ни одно из решений не соответствует жесткой системе правил, которые и сами принимаются под влиянием эмоций (хотя, безусловно, Л.Л. Фуллер не мог не знать о знаменитом "деле Дрейфуса", в ходе 
которого обнаружилось, что публика способна игнорировать факты, достоверно установленные в соответствии с надлежащей процедурой, если эти факты ей не нравятся [Юдин, 2020: 58-89]). В то же время он против прошения о помиловании, поскольку знает, что престарелый президент придерживается строгих принципов и чаще всего идет против мнения публики.

Поскольку мнения членов Верховного суда разделись поровну, было принято решение о том, что обвинение и приговор общего суда остаются в силе.

Впоследствии фуллеровский мысленный эксперимент детально проанализировала М. Дуглас и пришла к выводу, что представленный стандартный диапазон юридических точек зрения соответствует трем формам социальной жизни, проявляющихся в институциональной приверженности. Первая - индивидуальная, соответствует воззрениям первого судьи; вторая - сектантская, ее проповедует четвертый судья; третья - иерархическая, которая присуща третьему судье [Дуглас, 2020: 59]. Парадоксальным образом она отмечает, что сами запертые в пещере люди, сыгравшие в каннибальскую игру, обладали индивидуалистским сознанием, которые было выражено в отсутствии солидарности друг с другом. В том случае, если бы доминировала сектантская идеология, то они, очевидно, обрадовались бы своему положению, посчитав, что наступил Судный день; а если бы иерархическая, то на протяжении всех дней своего заточения они искали бы устраивающий всех иерархический принцип для выбора жертвы, но, вероятнее всего, так и не смогли бы его найти.

Более общий случай, не связанный ни с юридическими нормами, ни с каннибализмом, рассматривает А. Сен в своей «задаче о флейте» [Сен, 2016: 49-52]. Ее суть в том, что три ребенка - Анна, Боб и Карла - претендуют на флейту. Анна единственная, кто умеет на ней играть. Боб настолько беден, что не может себе позволить купить игрушки, поэтому флейта должна достаться ему. Карла сделала флейту собственными руками, для чего ей пришлось много и усердно трудиться на протяжении нескольких месяцев. Правильного решения представленной задачи не существует, хотя есть метод ее решения - разумное рассуждение [там же: 24]. Однако сделанный выбор свидетельствует о тех или иных моральных убеждениях и институциональных предрасположенностях, которые можно выявить как на индивидуальном уровне, так и в качестве доминант общественного сознания.

Сопоставление мысленного эксперимента со спелеологами и случая с флейтой позволило выделить четыре модели восприятия справедливости, в каждой из которых формируется своеобразное соотношение справедливости и закона: утилитаристская, либеральная, социалистическая и фаталистическая. Каждая из них существует как идеальный тип, поэтому в силу воздействия определенных обстоятельств не исключены их сочетания и выработка определенных правил по их переходу или переключению (например, схожие механизмы действуют в социологии градов Л. Болтански и Л. Тевено [Болтански, Тевено, 2013]).

Мы исходили из гипотезы, что выбор будущими юристами той или иной модели справедливости в качестве предпочтительной влияет на восприятие социальных практик, а знание об их отношении к практикам может быть использовано для прогнозирования влияния субъективных предпосылок на профессиональные занятия нормотворчеством и нормоприменением. Используемые нами модели не исчер- 
пывают всего многообразия представлений о соотношении закона и справедливости, но, на наш взгляд, позволяют изучить основные стратегии обоснования принятия решений в ситуации ценностно-нормативной неопределенности. Одно и то же решение может получить разные обоснования, которые делаются с опорой на конкретные нормы права и морали, что существенно затрудняет как сам процесс выбора, так и последующую общественную оценку принятого решения в форме одобрения или осуждения. Рассмотрим заявленные модели подробнее.

Утилитаристская модель. Анализируя данную модель, необходимо упомянуть еще один мысленный эксперимент - знаменитую дилемму вагонетки. Многочисленные вариации дилеммы ставят участника мысленного эксперимента в ситуацию принятия решения, не менее напряженную, чем та, в которой оказались спелеологи. Так, мужу предлагается решить, кого спасать - тонущую жену или тонущего ребенка при условии, что спасти он успеет только кого-то одного; рабочему нужно принять решение: толкнуть рядом стоящего коллегу на оголенный провод или не делать ничего, в результате чего от тока погибнет несколько человек, и т. п.

А. Сен интерпретирует утилитарную модель справедливости в гедонистическом ключе, полагая, что только Анна сможет получить истинное удовольствие от игры на флейте, поскольку умеет на ней играть. Однако можно предложить и толкование в духе классического утилитаризма: максимальная польза для максимального числа людей. Анна, играя на флейте, сможет доставить удовольствие не только себе, но и всем своим слушателям.

В контексте утилитаристской модели справедливости закон вполне может быть проигнорирован, если этого требуют интересы большинства. Элементы такого соотношения можно наблюдать в рассуждениях четвертого судьи в эксперименте со спелеологами. Требования практической мудрости оправдывают и вмешательство непрофессиональной, но широкой общественности в работу узких специалистов ради обеспечения такого образа справедливости, который поддерживается общественным мнением. Закон здесь предстает средством, а не целью, поэтому его можно интерпретировать как угодно для достижения должного результата. Результат является должным тогда, когда определение того, что справедливо, а что - нет, становится итогом общественного выбора.

Либеральная модель (у А. Сена - либертарианская) справедливости строится на приоритете в системе ценностей прав и свобод и неприемлемости идеи о том, что ради блага общества можно пожертвовать благом индивида. Либеральная модель прекрасно иллюстрирована в работах Дж. Ролза [Ролз, 1995]. Он интерпретирует справедливость как честность, полагая, что главной задачей является создание справедливых институтов; если таковые будут функционировать в обществе, достаточно будет только обеспечивать их бесперебойную работу. Дж. Ролз проповедует полный отказ от личных интересов в рассуждениях о справедливости, поэтому прибегает к модели так называемого исходного положения - гипотетической ситуации, в которой люди формулируют принципы справедливости и при этом не знают, каковы будут их личные интересы в обществе, которое будет жить по принятым ими принципам. По его мнению, каждый разумный человек в си- 
туации "исходного положения" будет стараться сформулировать такие правила, которые позволят обеспечить его потребности даже если он окажется в крайне неблагоприятном положении после того, как будет снят “занавес неведения".

В либеральной модели закон - ключевой нормативный регулятор, который справедлив по определению. Поэтому его следует уважать, подчиняться ему именно из уважения и всячески способствовать тому, чтобы все были равны перед законом, вне зависимости от своего социального, экономического, политического и т. п. статуса. Соотношение закона и справедливости в этой модели коррелирует с рассуждениями третьего судьи в кейсе Л. Л. Фуллера, призывающего к верности писаному закону и недопустимости толкования закона в угоду личным представлениям о справедливости. Институты должны иметь приоритет перед чаяниями индивидов, даже если они остро ощущают несправедливость и жаждут бороться с ней.

Социалистическая модель (у А. Сена - экономический эгалитаризм) справедливости работает по принципу перераспределения благ, но не так, как это заложено в либеральной модели Ролза. Здесь требования справедливости заходят гораздо дальше и предполагают не просто сокращение разрыва в достатке за счет грамотного общественного устройства, но и, в случае необходимости, принудительное перераспределение благ и уравнивание положения разных членов общества вне зависимости от личного труда и иных ресурсов, вложенных в производство благ. В контексте данной модели флейта должна достаться Бобу просто потому, что он беден.

Закон в социалистической модели обслуживает справедливость, понимаемую в соответствии с описанными ценностно-нормативными предпосылками. Если закон не способствует достижению социалистической справедливости, он должен быть изменен.

В социалистической модели справедливым по делу спелеологов может быть признано решение первого судьи: если закон содействует идеологическим параметрам общества, то следовать ему - разумно; если в каких-либо ситуациях, напротив, применение буквы закона может увеличить несправедливость, необходимо отказаться следовать закону.

Фаталистическая модель, отсутствующая в задаче, описываемой А. Сеном, предполагает справедливым в затруднительной ситуации воспользоваться жребием, который уравнивает шансы каждого на победу. Институт жребия - один из древнейших. В наибольшей степени фаталистическая модель справедливости, основанная на жребии, характерна для людей и сообществ с традиционалистскими установками. В их ценностно-нормативном фундаменте не обязательно заложен фатализм: это может быть и вера в Божественную волю, указывающую через жребий на наиболее справедливое решение в ситуации выбора, и надежда на справедливость предопределения.

Р. Кайуа, анализируя демократические практики в древних Афинах, отмечает, что “...при самом своем начале демократия весьма показательно колеблется между agon'oм и alea - двумя противоположными формами справедливости" [Кайуа, 2007: 128]. Agon (состязание) использовался только при выборе делегатов 
в органы политического управления Беотийского союза, где требуется представительная демократия; практически все остальные должности в Афинах определялись по жребию - alea (от лат. "игра в кости"). Если в состязании учитываются личные особенности вступающих в игру, то жребий уравнивает шансы всех, вне зависимости от личных особенностей.

Фаталистическая модель справедливости в некотором роде представлена в аргументах второго судьи по делу спелеологов. Будучи не в силах сделать выбор между справедливостью закона и личными представлениями о справедливости в конкретном кейсе, он фактически переложил бремя решения на других, положившись на волю судьбы. Не факт, что принятое решение будет с его точки зрения справедливым, но он априори соглашается с ним, выйдя из игры. Закон в фаталистический модели крайне важен, но, в отличие от либеральной модели, не тождествен справедливости. Поэтому, несмотря на уважение к закону, сторонники данной модели готовы отдать на откуп случаю принятие решения в ситуациях, когда применение закона противоречит их представлениям о справедливости.

\section{Материалы и методы}

Эмпирической основой исследования послужили результаты авторского анкетного опроса обучающихся на базе филиалов Всероссийского государственного университета юстиции (РПА Минюста России) в восьми российских городах - Ижевске, Казани, Калуге, Петрозаводске, Саранске, Санкт-Петербурге, Туле и Хабаровске. Он проведен с апреля по сентябрь 2020 г. Студенты участвовали удаленно, посредством онлайн-сервиса Google Forms. Это позволило, во-первых, свести к минимуму риски распространения коронавирусной инфекции; во-вторых, получить более искренние, как нам кажется, ответы на подчас сложные вопросы, связанные с моральным выбором.

Респонденты рекрутировались через представителей администрации структурных подразделений, профессорско-преподавательский состав и студенческие советы. В каждом филиале опрошено примерно по $10 \%$ обучающихся по очной форме. В исследовании участвовали свыше 1000 респондентов, после нормализации выборки по полу, форме и месту обучения отобрано 415 результативных анкет. Там, где это возможно, приведены результаты нашего предыдущего исследования, проведенного среди студентов того же вуза $(N=374)$ четыре года назад по схожей методике (см. [Коваль, Ушкин, 2018; Ушкин, Коваль, 2020]). Некоторые полученные в 2020 г. данные приведены в другой нашей работе, затрагивающей детерминанты норм права, морали и религии с точки зрения будущих юристов, а также вопросы о том, кто должен их устанавливать [Ушкин, Коваль, 2021].

На основании выделенных выше моделей и для их эмпирического подтверждения или же опровержения в инструментарий исследования мы включили вопрос, суть которого - выяснить, как бы респондент повел себя в гипотетической ситуации ценностно-нормативной неопределенности, в которой требуется справедливое разрешение спора. За основу был взят кейс А. Сена, в котором флейта была заменена на дудочку, а англоязычные имена - на привычные для российского общества Ваню, Машу и Петю. Если респондент указывал, что дудочка должна принадлежать Ване, который ее сделал, мы исходили из предположения, что он 
ориентирован на либеральную модель понимания справедливости; если на то, что дудочкой должна пользоваться Маша, которая умеет играть,- - на утилитаристскую; если на то, что дудочку необходимо отдать Пете,- - на социалистическую; если же респондент предлагал довериться случаю, то речь шла о фаталистской модели понимания справедливости, блистательно описанной Л. Л. Фуллером. Участникам исследования предлагался выбор из описанных альтернатив, а также была дана возможность дать собственный ответ. По нашему мнению, полученные ответы респондентов позволяют в определенной степени спрогнозировать их дальнейшие стратегии нормотворчества и нормоприменения (разумеется, в том случае, если они будут работать по получаемой юридической специальности).

Ценностно-нормативные установки мы выявляли не на основании типовых вопросов о том, что наиболее значимо для респондентов, а посредством определения их отношения к различным социальным практикам - абортам, гомосексуализму, коррупции и т. д. Такой подход в значительной степени конкретизирует доминирующие в рассматриваемой социальной группе студентов представления и «позволяет судить о целостности ценностно-нормативного пространства российского общества, его морально-нравственном состоянии, степени усвоения социальных норм западного либерализма" [Долгаева, Капкаева, 2015: 145].

\section{Результаты}

Прежде всего необходимо отметить, что сеновская задача для абсолютного большинства респондентов (91\%) не показалась неразрешимой. Главным бенефициаром, по мнению будущих юристов, оказался Петя, очень бедный мальчик, у которого совсем нет игрушек и который очень хочет поиграть на дудочке. О том, что музыкальный инструмент должен достаться ему, заявил почти каждый третий респондент (30\%). По большому счету мы наблюдаем востребованность социалистической модели мироустройства, при которой ресурсы перераспределяются в пользу тех, кто не имеет возможности их приобрести. Несколько чаще, чем в среднем по выборке, за решение отдать Пете дудочку выступают девушки (33\%), студенты первого курса (37\%) и верующие респонденты (35\%).

Более четверти опрошенных (27\%) предлагают Ване, Маше и Пете бросить жребий и довериться случаю. Это представляется наиболее простым решением, во всяком случае в фуллеровской логике, которое, однако, может привести к непрогнозируемым последствиям. Ведь пока участвующие в жеребьевке не знают конечного результата, они могут быть удовлетворены ситуацией; но как только жребий укажет на их проигрыш, не исключен бунт против такого решения. Более того, "дело о спелеологах" подтверждает, что этот подход к решению сложных моральных дилемм может быть губителен для его участников. Поэтому будущим российским юристам необходимо понимать и осознавать последствия своего выбора, ориентироваться на определенную систему норм (как, например, английские суды руководствуются “правилами Макнотена»). За решение бросить жребий чаще, чем в среднем по выборке, выступают юноши (32\%), студенты второго (34\%) и третьего (32\%) курсов. Можно предположить, что такое решение, как жребий, популярно у студенческой молодежи по той причине, что ее ценностнонормативные установки и профессиональные компетенции находятся в стадии 
становления. Приобретение опыта обоснования применения норм в ситуациях ценностно-нормативной неопределенности может в будущем привести к смене модели.

Каждый пятый (18\%) придерживается мнения, что дудочка должна остаться у Вани, который ее сделал. По всей видимости, для этих респондентов важны принципы частной собственности, свободных рыночных отношений - неотьемлемые признаки либерализма. При принятии юридических решений, вероятно, будет цениться индивидуальное благо в противовес общественному. Несколько чаще, чем в среднем по выборке, за Ваню выступают юноши (22\%), студенты второго курса (26\%) и неверующие респонденты (28\%).

Лишь $7 \%$ опрошенных считают, что дудочка должна остаться у Маши - единственной из детей, кто умеет на ней играть. Гедонистический утилитаризм не является значимым, при этом выгода от игры Маши в некоторой степени отложена. Отдать ей дудочку чаще, чем в среднем по выборке, намерены студенты четвертого курса (16\%), то есть те, кто прошел достаточный путь профессионализации.

В то же время представляется важным, что свое решение задачи сформулировал каждый десятый (9\%) респондент. Наиболее распространенный вариант предложить играть по очереди (5\%). Здесь мы наблюдаем реализацию принципа иерархии, о котором говорила М. Дуглас в отношении фуллеровского "дела о спелеологах". В соответствии с ее моделью, договориться об игре по очереди будет достаточно легко, а трудности могут начаться в определении того, кто должен быть первым, а кто - последним.

Показательно, что на декларативном уровне в ценностно-нормативном ключе фиксируется раскол между условными социалистами и либералами. Доля респондентов, которые в условиях своеобразного “занавеса неведения" выбрали общество, где все равны, составила $38 \%$; доля тех, кто в аналогичных обстоятельствах выбрал общество, где каждый получает по способностям - 40\%. При этом первый тип общества чаще, чем в среднем по выборке, выбирают социалисты (48\%) и фаталисты (46\%), а второй - либералы (60\%) и утилитаристы (48\%). Еще одна альтернатива - общество, в котором в целом все равны, но некоторые находятся в привилегированном положении,- востребована немногим более чем каждым десятым респондентом (14\%). Еще 7 \% затруднились с ответом, а 1 \% предложил свой вариант.

Также мы замерили значимость соблюдения будущими юристами норм права, морали и религии по десятибалльной шкале. В целом мы получили достаточно высокие результаты по первым двум позициям. Для норм права средний балл составил 8,58, для норм морали - 8,47, для норм религии - 5,51. Примечательно, что внутри выделенных нами групп - либералов, утилитаристов, социалистов и фаталистов - значения несколько различаются, что позволяет говорить о дифференциации приоритетных социальных нормативных систем в этих группах (см. табл. 1).

Для социалистов, в отличие от всех остальных групп, мораль ценится несколько выше права. Это подтверждает описанную нами взаимосвязь закона и справедливости в социалистической модели. Здесь также можно установить корреляции с коммунитаристским проектом "хорошего общества", где ключевым 
нормативным регулятором является не закон, а "голос морали" [Etzioni, 2002]. Неудовлетворенная потребность в неформальных регуляторах социальной жизни вероятно, служит одной из причин того, что именно социалисты критично настроены к оценке современного российского общества.

Таблица 1. Значимость соблюдения студентами-юристами норм права, морали и религии (от 1 до 10 баллов, где 1 балл - совсем не важно, а 10 баллов - очень важно) (в баллах)

\begin{tabular}{|c|c|c|c|c|c|}
\hline & Все опрошенные & Либералы & Утилитаристы & Социалисты & Фаталисты \\
\hline Нормы права & 8,58 & 8,68 & 8,59 & 8,57 & 8,55 \\
\hline Нормы морали & 8,47 & 8,25 & 7,93 & 8,74 & 8,32 \\
\hline Нормы религии & 5,51 & 4,75 & 4,97 & 5,95 & 5,39 \\
\hline
\end{tabular}

В то же время будущие юристы отмечают наличие определенных зависимостей В континууме «право - мораль - религия". В частности, каждый третий опрошенный (35\%) указывает на их тесную взаимосвязь; половина (53\%) считает, что нормы права, морали и религии отчасти связаны, а отчасти нет. Менее десятой части (7\%) заявляют, что, по их мнению, прямая связь между различными нормативными системами отсутствует; почти столько же (6\%) затруднились с ответом. Чаще остальных о тесной взаимосвязи заявляют либералы (40\%); о частичной взаимосвязи - утилитаристы (62\%); о ее отсутствии - социалисты (10\%).

Отношение респондентов к различным социальным практикам, находящимся в центре религиозных и моральных (реже - правовых) споров, неоднозначно. Резко осуждаются коррупция, наркомания, супружеская измена, пьянство и алкоголизм, неприязнь к представителям других национальностей, проституция, оскорбление чувств верующих, сексуальная распущенность и уклонение от уплаты налогов. Обращает на себя внимание тот факт, что в динамике с 2016 по 2020 г. среди будущих юристов значительно выросла нетерпимость по отношению к проявлениям неприязни к представителям других национальностей (на 19\%), коррупции (на 11\%) и цензуре информации (на 11\%). Напротив, все менее резкому осуждению подвергаются практики гомосексуализма (на $28 \%$ ), абортов (на $24 \%$ ), суррогатного материнства (на $12 \%$ ) и уклонения от службы в армии (на $11 \%$ ) (см. табл. 2).

Таблица 2. Уровень осуждения студентами-юристами различных социальных практик (в \% от всех опрошенных)

\begin{tabular}{|l|c|c|}
\hline & $\mathbf{2 0 1 6}$ & $\mathbf{2 0 2 0}$ \\
\hline Коррупция & 74 & 85 \\
\hline Наркомания & 82 & 81 \\
\hline Супружеская измена & 76 & 69 \\
\hline Пьянство, алкоголизм & 68 & 68 \\
\hline Неприязнь к представителям других национальностей & 42 & 61 \\
\hline Проституция & 61 & 58 \\
\hline Оскорбление чувств верующих & 52 & 58 \\
\hline Сексуальная распущенность & 55 & 53 \\
\hline
\end{tabular}




\begin{tabular}{|l|c|c|}
\hline & $\mathbf{2 0 1 6}$ & $\mathbf{2 0 2 0}$ \\
\hline Уклонение от уплаты налогов & 47 & 52 \\
\hline Цензура информации & 34 & 45 \\
\hline Гомосексуализм & 60 & 32 \\
\hline Уклонение от службы в армии & 42 & 31 \\
\hline Аборты & 49 & 25 \\
\hline Эвтаназия & 27 & 23 \\
\hline Суррогатное материнство & 22 & 10 \\
\hline $\begin{array}{l}\text { Сожительство (фактический брак, неформальный брак, факти- } \\
\text { ческие брачные отношения, бракоподобные отношения) }\end{array}$ & 17 & 10 \\
\hline
\end{tabular}

Но целостность нормативно-правового континуума в восприятии выделенных групп респондентов - либералов, утилитаристов, социалистов и фаталистов по многим вопросам отсутствует. Так, либералы существенно чаще, чем в среднем по выборке, демонстрируют нетерпимость к коррупции (97\%), наркомании (89\%), неприязни к представителям других национальностей (76\%) и цензуре информации (68\%); при этом они более лояльны по отношению к супружеской измене (63\%), оскорблению чувств верующих (51\%), сексуальной распущенности (45\%), уклонению от службы в армии (24\%) и абортам (16\%). Это в очередной раз подтверждает корректность определения соотношения социальной справедливости и закона в либеральной модели: если коррупция, наркомания, цензура, дискриминация по национальному признаку запрещены законом, то супружеская измена и аборт если и осуждаются, то не в правовом, а в моральном или религиозном ценностно-нормативном контекстах. Норма об оскорблении чувств верующих включена в действующее российское законодательство ${ }^{1}$, однако является весьма спорной и с момента введения до настоящего времени постоянно становится предметом критики как профессиональных юристов, так и широкой общественности (хотя с 2016 по 2020 г. нетерпимость к этой практике выросла на 6\%). В то же время уклонение от прохождения военной и альтернативной гражданской службы также уголовно наказуемое деяние ${ }^{2}$, но эта норма не подвергается столь резкой критике. Таким образом, либералы чаще других нетерпимы к незаконным практикам (за исключением практики уклонения от службы в армии) и демонстрируют большую терпимость к практикам, которые хотя и не считаются нормативными, по крайнем мере, частью общества, но прямо не запрещены законом.

Утилитаристы чаще, чем в среднем по выборке, настроены негативно по отношению к практикам гомосексуализма (48\%) и суррогатного материнства (21\%); напротив, они не так категорично воспринимают коррупцию (79\%), супружескую измену (55\%), проституцию (48\%), неприязнь к представителям других национальностей (48\%), оскорбление чувств верующих (45\%), цензуру информации (31\%) и эвтаназию (14\%). Это самая непредсказуемая группа, которая может демонстрировать высокую нетерпимость к легитимным практикам и в то же время толерантно относиться к тому, что прямо запрещено законом и постоянно

${ }_{1}^{1}$ См. ст. 148 Уголовного Кодекса Российской Федерации от 13.06.1996 № 63-ФЗ в ред. Федерального закона от 29.06.2013 № 136-Ф3.

2 См. ст. 328 Уголовного Кодекса Российской Федерации от 13.06.1996 № 63-Ф3. 
осуждается как властью, так и обществом в публичном дискурсе. Практически невозможно прогнозировать, каким образом ценностно-нормативные убеждения этой группы скажутся на нормотворческой и нормоприменительной деятельности в том случае, если студенты будут работать по специальности и профессионально заниматься нормативным регулированием социальных практик.

Социалисты чаще, чем в среднем по выборке, осуждают супружескую измену (75\%), проституцию (68\%), сексуальную распущенность (60\%) и аборты (35\%); реже остальных их порицания удостаиваются коррупция (76\%), неприязнь к представителям других национальностей (51\%), пьянство и алкоголизм (61\%) и цензура информации (33\%). Здесь мы наблюдаем практически полную противоположность соотношения закона и справедливости, чем в группе либералов. Наибольшая нетерпимость демонстрируется к практикам, запрещенным религиозными и моральными нормами (по крайней мере, это актуально для части общества), но прямо не запрещенным законом (за исключением проституции, за занятие которой привлекают к административной ответственности ${ }^{3}$, а за вовлечение и организацию - к уголовной ${ }^{4}$ ). Напротив, менее резкое осуждение вызывают незаконные практики (за исключением пьянства и алкоголизма, которые прямо не запрещены, хотя состояние алкогольного опьянения в некоторых условиях может служить основанием для привлечения к административной ответственности ${ }^{5}$, а в уголовном праве рассматривается как обстоятельство, отягчающее наказание ${ }^{6}$, или как признак состава преступления ${ }^{7}$ ).

Среди фаталистов значимых отличий в восприятии ценностей от средних значений по выборке не обнаружено.

\section{Выводы}

Результаты проведенного исследования позволяют утверждать, что среди российских юристов, находящихся в стадии приобретения профессиональных знаний и навыков, фиксируется глубокий ценностно-нормативный раскол. По всей видимости, вынесенный ими вердикт по "делу о спелеологах" на практике не отличался бы от решения, описанного самим Л.Л. Фуллером. Однако лишь с той оговоркой, что либерала, чтящего закон, фаталиста, уважающего институт жребия, или социалиста, приверженного представлениям о социальной справедливости, встретить сегодня гораздо проще, чем, например, утилитариста, стремящегося к максимизации общего блага. Можно предположить, что ситуации ценностнонормативной неопределенности по-прежнему не только будут порождать неоднородность правоприменительной практики, но и влиять на структуру ценностнонормативных кодов общества в целом.

\footnotetext{
${ }^{3}$ Ст. 6.11 Кодекса Российской Федерации об административных правонарушениях от 30.12.2001 № 195-Ф3.

4 Статьи 240, 241 Уголовного Кодекса Российской Федерации от 13.06.1996 № 63-Ф3; также уголовно наказуемым деянием является получение сексуальных услуг несовершеннолетнего (ст. 240.1, введенная в УК РФ Федеральным законом от 28.12.2013 № 380-Ф3).

5 K административным правонарушениям относится употребление алкоголя в неположенных местах, появление в состоянии опьянения в общественном месте, управление транспортным средством в состоянии опьянения и т. п.

6 С. 63 Уголовного Кодекса Российской Федерации от 13.06.1996 № 63-Ф3.

7 См., например, ч. 2, 4, 6 ст. 264 Уголовного Кодекса Российской Федерации от 13.06.1996 № 63-Ф3.
} 
Наиболее острые, практически непримиримые противоречия наблюдаются между либералами и социалистами. Для первых важно, чтобы в будущем каждый мог получить по возможностям; вторые ориентированы на такой идеал будущего, в котором все были бы равны. Кроме того, в данных группах наблюдается противоположное соотношение закона и справедливости: если для либералов законопослушность и закон как нормативный регулятор являются базовыми ценностно-нормативными установками, то социалисты чаще отдают предпочтение социальной справедливости, осуждая практики, которые, хотя и разрешены законом, но порицаются с точки зрения религии и общественной морали (по крайней мере, религиозных и моральных убеждений, характерных для части общества).

Отметим, что в период с 2016 по 2020 г. выросла нетерпимость главным образом к незаконным практикам (коррупция, дискриминация по национальному признаку, цензура, оскорбление чувств верующих, уклонение от уплаты налогов), а практики, не запрещенные законом, но неоднозначные либо ненормативные с точки зрения морали и религии (супружеская измена, сексуальная распущенность, гомосексуализм, аборты, эвтаназия, суррогатное материнство, сожительство), напротив, стали вызывать меньшее осуждение. Были выявлены и незаконные практики, к которым будущие юристы стали относиться терпимее : уклонение от службы в армии и проституция.

Впрочем, повод для оптимизма есть, и весьма существенный. Практически вне зависимости от своих ценностно-нормативных воззрений, будущие юристы предъявляют достаточно высокие нравственные требования по отношению к себе, стараются соблюдать действующее законодательство и принимать обоснованные решения в ситуациях ценностно-нормативной неопределенности. Они не воспринимают триаду «право - мораль - религия" как пустой звук и в большинстве случаев понимают существующие взаимосвязи (путь и с некоторыми оговорками). Но если либералы в этом воображаемом континууме чаще верны принципам законности, то поведение социалистов в большей степени обусловлено верой в традиционные ценности и религиозные установки.

\section{Список литературы (References)}

Болтански Л., Тевено Л. Критика и обоснование справедливости: Очерки социологии градов / пер. с фр. О.В. Ковеновой. М.: Новое литературное обозрение, 2013. Boltanski L., Thévenot L. (2013) De la Justification: Les Économies de la Grandeur. Moscow: New Literary Observer. (In Russ.)

Вахштайн В.С. Дело о повседневности. СПб. : ЦГИ Принт, 2015.

Vakhstein V.S. (2015) The Case of Everyday Life. Saint Petersburg: TsGI Print. (In Russ.)

Долгаева Е. И., Капкаева Н. К. Отношение православной и мусульманской молодежи к социальным практикам, противоречащим нормам религиозной морали // Регионология. 2015. № 2. С. 144-151.

\footnotetext{
8 Разница в показателе нетерпимости к наркомании незначительна $(0,9 \%)$.
} 
Dolgaeva E. I., Kapkaeva N. K. (2015) Attitudes of the Orthodox and Muslim Youth to Social Practices Contrary to the Norms of Religious Morality. Russian Journal of Regional Studies. No. 2. P. 144-151. (In Russ.)

Дуглас М. Как мыслят институты? / пер. с англ. А. Корбута М. : Элементарные формы, 2020.

Douglas M. (2020) How Institutions Think. Moscow: Elementarnyye Formy. (In Russ.)

Катомина В.А., Санисалова Н. А. Законность и справедливость: единство, различия и взаимодействие // Вестник Пензенского государственного университета. 2013. № 2. С. 40-45.

Katomina V. A. Sanisalova N. A. (2013) Legality and Justice: Unity, Difference and Interaction. Vestnik of Penza State University. No. 2. P. 40-45. (In Russ.)

Кайуа Р. Игры и люди; Статьи и эссе по социологии культуры / сост., пер. с фр. и вступ. ст. С. Н. Зенкина. М.: ОГИ (Объединенное Гуманитарное Издательство), 2007.

Kayua R. (2007) Man, Play and Games. Papers and Essays on Sociology of Culture. Moscow: OGI Publ. (In Russ.)

Коваль Е. А., Ушкин С.Г. Пути России в будущее. Готово ли наше общество стать "хорошим"? // Социологические исследования. 2018. № 2. С. 136-145. https:// doi.org/10.7868/S0132162518020149.

Koval E. A., Ushkin S. G. (2018) Russia's Paths in the Future: Is Our Society Ready to Become a "Good Society"? Sociological Studies. No. 2. P. 136-145. https:// doi.org/10.7868/S0132162518020149. (In Russ.)

Козырева П. М., Смирнов А.И. Эволюция правовых представлений россиян: законопослушность или справедливость? // Полис. Политические исследования. 2020. № 5. C. 75—89. https://doi.org/10.17976/jpps/2020.05.06.

Kozyreva P. M., Smirnov A. I. (2020) The Evolution of Russian Citizens' Views on the Law: Law Abidance or Justice? Polis. Political Studies. No. 5. P. 75-89. https:// doi.org/10.17976/jpps/2020.05.06. (In Russ.)

Настина Е.А., Девятко И.Ф. Моральная оценка себя: разработка и апробация русскоязычного инструментария // Мониторинг общественного мнения: экономические и социальные перемены. 2021. No 2. C. 4-27. https://doi.org/10.14515/ monitoring.2021.2.1720.

Nastina E. A., Deviatko I.F. (2021) Moral Self-Evaluation: Developing and Validating Methodology for Russian-Speaking Populations. Monitoring of Public Opinion: Economic and Social Changes. No. 2. P. 4-27. https://doi.org/10.14515/monitoring. 2021.2.1720. (In Russ.)

Римский В.Л. Справедливость от государства: ожидания и реальность // Власть и элиты. 2019. Т. 6. № 2. С. 156-175.

Rimskiy V. L. (2019) Fairness from the State: Expectations and Reality. Power and Elites. Vol. 6. No. 2. P. 156-175. (In Russ.)

Ролз Дж. Теория справедливости / пер. с англ. В. Целищева, В. Карпович, А. Шевченко. Новосибирск: Издательство Новосибирского университета, 1995. 
Rawls J. (1995) A Theory of Justice. Novosibirsk: Novosibirsk University Press. (In Russ.)

Сен А. Идея справедливости / пер. с англ. Д. Кралечкина. М.: Изд-во Института Гайдара: Фонд "Либеральная миссия", 2016.

Sen A. (2016) The Idea of Justice. Moscow: Gaidar Institute Publishing House; Liberal Mission Foundation. (In Russ.)

Тихонова Н.Е. Особенности нормативно-ценностной системы российского общества через призму теории модернизации // Terra Economicus. 2011. T. 9. № 2. C. $60-85$.

Tikhonova N. E. (2011) Special Features of Normative Value System of Russian Society Within the Modernization Theory. Terra Economicus. Vol. 9. No. 2. P. 60-85. (In Russ.)

Ушкин С. Г., Коваль Е. А. Социальное будущее в представлениях будущих российских юристов // Вестник Института социологии. 2020. Т. 11. № 3. С. 28-42. https:// doi.org/10.19181/vis.2020.11.3.661.

Ushkin S. G., Koval E. A. (2020) The Future of Society According to Future Russian Lawyers. Bulletin of the Institute of Sociology. Vol. 11. No. 3. P. 28-42. https://doi.org/10.19181/ vis.2020.11.3.661. (In Russ.)

Ушкин С. Г., Коваль Е. А. Субъекты нормотворчества в представлениях студентовюристов // Социологические исследования. 2021. № 2. С. 57-66.

Ushkin S. G., Koval E. A. (2021) The Subjects of Norm-Creating in the Representations of Law Students. Sociological Studies. No. 2. P. 57-66. (In Russ.)

Фуллер Л. Л. Дело спелеологов / пер. с англ. В. Целищева // Харт Г. Л.А. Философия и язык права. М.: Канон+ :Реабилитация, 2017. С. 343-372.

Fuller L. L. (2017) The Case of Cavers. In: Hart G. L.A. Philosophy and language of law. Moscow: Canon +; Rehabilitation. P. 343-372. (In Russ.)

Цыбулевская О.И., Милушева Т. В. Справедливость в праве: аксиологический подход // Вестник Поволжского института управления. 2017. Т. 17. № 5. С. 52-59. https://doi.org/10.22394/1682-2358-2017-5-52-59.

Tsybulevskaya O. I., Milusheva T. V. (2017) Equity in Law: An Axiological Approach. Bulletin of the Volga Region Institute of Administration. Vol. 17. No. 5. P. 52-59. (In Russ.)

Черняева А. В. Единство принципов законности и справедливости в современном гражданском обществе // Вестник Удмуртского университета. Экономика и право. 2009. № 1. C. $126-134$.

Chernyaeva A. V. (2009) Unity of Principles of Legality and Justice in Modern Civil Society. Bulletin of the Udmurt University. Economics and Law. No. 1. P. 126-134.

Юдин Г.Б. Общественное мнение, или Власть цифр. СПб.: Издательство Европейского университета в Санкт-Петербурге, 2020.

Yudin G. B. (2020) Public Opinion. The Power of Numbers. Saint Petersburg: EUSP Press. (In Russ.)

Binns R. (2020) Human Judgment in Algorithmic Loops: Individual Justice and Automated Decision-Making. Regulation \& Governance. P. 1-15. https://doi.org/ 10.1111/rego.12358. 
Etzioni A. (2002) The Good Society. Seattle Journal of Social Justice. Vol. 1. No. 1. P. 83-96.

Sangroula Y. (2021) Social Justice Jurisprudence of Clinical Education Programme: A Paradigm Shift from Legal Education to Justice Education. Jindal Global Law Review. Vol. 11. P. 339-364. https://doi.org/10.1007/s41020-020-00131-4.

Tan Z. (2011) Research on Legal Education of Contemporary College Students. In: Wang Y. (ed.) Education and Educational Technology. Advances in Intelligent and Soft Computing. P. 423-429. Berlin, Heidelberg: Springer. https://doi.org/10.1007/ 978-3-642-24775-0_67.

Wai-Sang Wu R., Wing-Hung Lo C., Liu N. (2020) Legal Professionalism and the Ethical Challenge for Legal Education: Insights from a Comparative Study of Future Lawyers in Greater China. The China Quarterly. Vol. 244. P. 1118-1139. https://doi.org/ 10.1017/S0305741020001095.

van Schilfgaarde P. (2019) Law and Life. Why Law? New York: Springer. https://doi.org/ 10.1007/978-3-030-01848-1. 